\title{
LEVELS OF STUDENTS' MATHEMATICS ANXIETIES AND THE IMPACTS ON ONLINE MATHEMATICS LEARNING
}

\author{
Siti Lailiyah*, Sihhatul Hayat, Siti Urifah, Maunah Setyawati \\ Islamic State University of Sunan Ampel, Indonesia \\ *e-mail: lailiyah@uinsby.ac.id
}

\begin{abstract}
It is widely assumed that anxieties tend to lead to low mathematics performance. The purpose of this study was to describe the levels of students' mathematics anxieties and the impacts on mathematics learning achievement in online mathematics learning. The study was a quantitative survey. The research instrument was questionnaire consisting of four elements of physiological, cognitive, affective, and behavioral aspects. The subjects were 109 mathematics education students who were willing to be the research participants. The data were collected using mathematics anxiety questionnaires and documentation of students' mathematics learning achievement. The data analyses used descriptive statistics and confirmatory factor analysis with Structural Equation Modeling of the Lisrel program. The findings show that the levels of all aspects of students' mathematics anxieties in online mathematics learning were at the moderate level. The anxiety aspects that affect students' mathematics learning achievement in online mathematics learning were of the affective and cognitive categories, while the physiological and behavioral aspects do not affect mathematics learning achievement. A research implication is for the teacher to pay attention to the cognitive and affective aspects of the students' mathematics anxieties.
\end{abstract}

Keywords: mathematics anxiety, mathematics anxiety level, mathematics learning achievement, online mathematics learning.

\section{LEVEL KECEMASAN MATEMATIKA MAHASISWA DAN DAMPAKNYA PADA PEMBELAJARAN MATEMATIKA ONLINE}

\begin{abstract}
Abstrak: Secara luas diasumsikan bahwa kecemasan cenderung menyebabkan kinerja matematika yang rendah. Tujuan penelitian ini adalah mendeskripsikan tingkat kecemasan matematika mahasiswa dan adakah dampak kecemasan matematika terhadap prestasi belajar dalam pembelajaran matematika online. Jenis penelitian ini adalah penelitian kuantitatif survei. Instrumen penelitian berupa angket kecemasan matematika yang terdiri atas empat aspek, yaitu aspek fisiologi, afektif, kognitif, dan perilaku. Subjek penelitian adalah 109 mahasiswa pendidikan matematika yang dengan sukarela bersedia menjadi sampel penelitian. Pengumpulan data menggunakan kuisioner angket kecemasan matematika dan dokumentasi prestasi belajar matematika mahasiswa. Analisis data menggunakan statistik deskriptif dan confirmatory factor analysis dengan Structural Equation Model dengan bantuan program Lisrel. Hasil penelitian menunjukkan bahwa level semua aspek kecemasan matematika mahasiswa dalam pembelajaran matematika online berada di level sedang. Aspek-aspek kecemasan yang memengaruhi prestasi belajar matematika mahasiswa dalam pembelajaran matematika online, yaitu aspek afektif dan kognitif, sedangkan aspek fisiologi dan perilaku tidak memengaruhi prestasi belajar matematika. Hal ini menyiratkan perlu adanya perhatian dosen terhadap aspek kecemasan afektif dan aspek kognitif.
\end{abstract}

Kata Kunci: kecemasan matematika, level kecemasan matematika, hasil belajar matematika, pembelajaran matematika online.

\section{INTRODUCTION}

In 2020, the world was attacked by the Covid-19 pandemic that caused anxieties among its inhabitants especially school and university students with their learning activities (Ayyala, Taylor, \& Callahan, 2020). These anxieties were initiated by the changes in the instructional systems from the face-to-face to the on-line modes (Almaiah, Al-Khasawneh, \& Althunibat, 2020; Bloom, Reid, \& Cassady, 2020; Kim, 2020).

Various efforts were conducted by all 
countries in order that instructional processes remained running during the Covid-19 pandemic, from altering the curriculum and setting up on-line evaluation (Daniel, 2020) to running virtual learning systems (Ehrlich, Mc Kenney, \& Elkbuli, 2020). Various on-line platforms were used in the learning processes including e-learning, virtual labs (Ray \& Srivastava, 2020), digital or technological connections (Nuere \& de Miguel, 2020), and distance learning (Schneider \& Council, 2020). Germany, Austria, and Switzerland used school barometres (Huber \& Helm, 2020; Kerres, 2020), China used a system of open educational resources and open educational practices (Huang, Tlili, Chang, Zhang, Nascimbeni, \& Burgos, 2020), New Jersey used community-based programs (Iyengar \& Shin, 2020), and Africa used an instructional system for adult education (Lopes \& McKay, 2020; Ramrathan, 2020; Spaull, 2020). The main challenges of the distance instructional systems during the Covid-19 pandemic were changes in the learning management, technical problems in the e-learning system, and financial supports (Almaiah et al., 2020; d'Orville, 2020). Online learning has its strengths and weaknesses. Students' perceptions on on-line learning are quite positive; on-line learning makes learning not monotonous only in the classroom, there is efficiency in time and materials that are easily accessible (Agarwal \& Kaushik, 2020; Bal, Arslan, Budhrani, Mao, Novak, \& Muljana, 2020). Besides, impacts of positive perceptions are felt by students of on-line learning that integrates ICT (Information, Communication, and Technology) (Lubis, 2018). However, there are weaknesses in on-line learning such as those experienced by Bangladesh and other lowincome countries who do not have technological accesses and on-line school materials and have financial difficulties in the household (Mamun, Chandrima, \& Griffiths, 2020). These weaknesses can create learning anxieties, especially in mathematics learning.

Mathematics anxieties often occur in students learning mathematics. One causing factor is the perception that learning mathematics or solving a mathematical problem is difficult (Gafoor \& Kurukkan, 2015; Tambychik \& Meerah, 2010). It is, therefore, true that mathematics anxieties become an important topic to study (Ayyala et al., 2020). The importance of studying mathematics anxieties arises from the fact that mathematics anxieties have a direct influence on mathematics learning; the higher the mathematics anxieties, the lower the mathematics achievements (Guita \& Tan, 2018; Pourmoslemi, Erfani, \& Firoozfar, 2013; Vásquez-Colina, Gonzalez-DeHass, \& Furner, 2014). Besides, mathematics anxieties also have negative effects and relations with performance, achievement, learning motivation, decisionmaking abilities, and positive attitudes towards mathematics (Huang, Zhang, \& Hudson, 2019; Lewis, 2020; Morsanyi, Busdraghi, \& Primi, 2014).

Mathematics anxieties are caused by two factors; these are (1) personal factors when a person has unpleasant experiences in leaning mathematics or problems in mathematics earning in the past (Bekdemir, 2010); and (2) environmental factors such as the teachers or parents' attitudes towards the students' performances (Chaman, Beswick, \& Callingham, 2014; Soni \& Kumari, 2017). In online learning, mathematics anxieties are caused by, among others, the low level of the learning interactivities (Allen \& Vallée-Tourangeau, 2016), on-line evaluation with no remedies (Lewis, 2020), and low learning habits (Chen, Hsu, \& Chen, 2013).

In terms of the aspects of mathematics anxieties, according to Greenberger \& Padesky (1995), there are physiological, affective, cognitive, and behavioral aspects of mathematics anxieties. The physiological aspect of mathematics anxieties is related to physical conditions such as over-sweating, hand and lip trembling, stomach ache, head ache, and increase in heart beats. The affective aspects are shown in the feelings of nervousness, fright, tense, and anxiety. The cognitive aspects occur in difficulties to concentrate, make decision, and sleep. Meanwhile, the behavioral aspects appear in purposeful attempts to avoid the on-line class, walking up and down, and clicking fingers.

The measurement of mathematics anxieties of Rayner, Pitsolantis, \& Osana (2009) uses RMARS (Revised Mathematics Anxiety Rating Scale) in three levels: high, moderate, and low. In the meantime, there are five categories of mathematics anxieties: very high, high, moderate, low, very low (Nurhayati, Marhayani, Chang, \& Naaranoja, 2019; Pourmoslemi et al., 2013). 
In the present study, the five-level category of mathematics anxieties is used, since the score interval is not so wide so that measurement of the anxiety levels is comparably accurate.

Reducing students' mathematics anxieties in learning can be done by, among others, the metacognitive technique of self-regulated learning (Kramarski, Weisse, \& KololshiMinsker, 2010; Skaalvik, 2018), involvement of the parents (Demirtaş \& Uygun-Eryurt, 2020), and creating conducive learning environment (McMinn \& Aldridge, 2019; Taylor \& Fraser, 2013). However, research shows that, in many countries, students' levels of mathematics anxieties are still high; such as in Serbia (Radišić, Videnović, \& Baucal, 2015) and Norwegia (Skaalvik, 2018). Meanwhile, the levels of mathematics anxieties in students of the elementary school in Indonesia are at the low level (Nurhayati et al., 2019).

There are a number of studies on mathematics anxieties, such as the ones by Radišić et al. (2015), in Serbia, concerning mathematics anxieties level of 15 year-old students; Nurhayati et al. (2019), in Indonesia, concerning mathematics anxieties level of elementary school children; and Skaalvik (2018) concerning the relation between mathematics anxieties level and mathematics performance of junior high school students. These studies have been conducted prior to the Covid-19 pandemic. However, research on mathematics anxieties has not been done during or after the pandemic. Studies on mathematics anxieties during the Covid-19 may give different results.

The need for research on mathematics anxieties during the Covid-19 pandemic is felt in order to find out students' readiness in mathematics learning during this new-normal time. Besides, by knowing students' mathematics anxieties, teachers will be able to better prepare instruction by way of various learning strategies and minimalizing mathematics anxieties during the on-line learning. The objective of the present study is to describe the level of students' mathematics anxieties and to see the impacts on their mathematics achievement during the online learning.

\section{METHOD}

The study uses a quantitative survey as the research design to measure the students' level of mathematics anxieties and to see whether there is an impact of mathematics anxieties on students' learning achievement during their on-line mathematics learning. By way of random sampling, a total of 109 students of the Mathematics Study Program of UIN Sunan Ampel Surabaya participated in the voluntary completion of the mathematics anxieties questionnaires. The participants took the on-line mathematics learning in one semester during the even semester of 2020. Description of the participants can be seen in Tabel 1 .

\section{Tabel 1. Research Subjects}

\begin{tabular}{clccc}
\hline \multirow{2}{*}{ No. } & \multirow{2}{*}{ Student } & \multicolumn{2}{c}{ Gender } & \multirow{2}{*}{ Total } \\
\cline { 3 - 4 } & & Female & Male & \\
\hline 1. & Semester 2 & 51 & 2 & 53 \\
2. & Semester 4 & 33 & 5 & 38 \\
3. & Semester 6 & 16 & 2 & 18 \\
\hline & Total & 100 & 9 & 109 \\
\hline
\end{tabular}

The research instrument was the mathematics anxieties questionnaire. This is in line with Baloğlu \& Zelhart (2007) and Soni \& Kumari (2017) who stated that mathematics anxieties can be measured by a questionnaire. The data were responses to the mathematics anxieties questionnaire and scores of students' mathematics learning achievements. Results of the mathematics anxieties questionnaire were used to look at the levels of students' mathematics anxieties while the students' achievement scores were used to see the impacts of mathematics anxieties upon mathematics learning achievements.

The anxiety questionnaire was developed on the four observed aspects of affective, physiological, cognitive, and behavioral (see Table 2). The questionnaire was disseminated through the Google format. Each questionnaire item consisted of five options. The questionnaire had been validated by four faculty members of mathematics education. Validation was conducted on the basis of the pre-developed table of specifications. Using the Aiken formula, the validity co-efficient value $(\mathrm{V})$ for each item was found to range between .562 and .813 with an average score of .696. It means that the questionnaire items were categorizable as valid. Meanwhile, results of the reliability test using Alpha Cronbach via SPPS showed a value of .771. This means that the questionnaire is reliable 
Tabel 2. Indicators of Mathematics Anxieties

\begin{tabular}{|c|c|c|c|c|c|}
\hline No. & $\begin{array}{l}\text { Anxiety } \\
\text { Aspect }\end{array}$ & Indicator & $\begin{array}{l}\text { Questionnaire } \\
\text { Item }\end{array}$ & $\begin{array}{l}\text { Item } \\
\text { Number }\end{array}$ & Code \\
\hline \multirow[t]{3}{*}{1.} & \multirow[t]{3}{*}{ Physiology } & \multirow{3}{*}{$\begin{array}{l}\text { 1. Learner can explain problems } \\
\text { of physical signs that are } \\
\text { experienced during the learning } \\
\text { process }\end{array}$} & \multirow[t]{3}{*}{ Unfavourable } & 20 & PHY1 \\
\hline & & & & 8 & PHY2 \\
\hline & & & & 6 & PHY3 \\
\hline \multirow[t]{6}{*}{2.} & \multirow[t]{6}{*}{ Cognitive } & \multirow[t]{2}{*}{ 1. Ability to overcome problems } & \multirow[t]{2}{*}{ Favourable } & 13 & COG1 \\
\hline & & & & 11 & COG2 \\
\hline & & \multirow{4}{*}{$\begin{array}{l}\text { 2. Over-cautious over threats of } \\
\text { bad experiences }\end{array}$} & \multirow[t]{3}{*}{ Favourable } & 1 & COG3 \\
\hline & & & & 5 & COG4 \\
\hline & & & & 3 & COG5 \\
\hline & & & Unfavourable & 14 & COG6 \\
\hline \multirow[t]{7}{*}{3.} & \multirow[t]{7}{*}{ Affective } & \multirow{2}{*}{$\begin{array}{l}\text { 1. Learner shows responses of } \\
\text { fright of mathematics }\end{array}$} & \multirow[t]{2}{*}{ Unfavourable } & 2 & AFF1 \\
\hline & & & & 16 & AFF2 \\
\hline & & \multirow{5}{*}{$\begin{array}{l}\text { 2. Learner shows responses of } \\
\text { nervousness of mathematics } \\
\text { 3. Learner shows responses of } \\
\text { anxieties of mathematics }\end{array}$} & Unfavourable & 17 & AFF3 \\
\hline & & & Favourable & 19 & AFF4 \\
\hline & & & Unfavourable & 18 & AFF5 \\
\hline & & & Unfavourable & 4 & AFF6 \\
\hline & & & & 12 & AFF7 \\
\hline \multirow[t]{5}{*}{4.} & \multirow[t]{5}{*}{ Behavioral } & $\begin{array}{l}\text { 1. Too many actions to avoid } \\
\text { problems }\end{array}$ & - & - & - \\
\hline & & \multirow{4}{*}{$\begin{array}{l}\text { 2. Learner's behaviours when } \\
\text { responding to instruction given } \\
\text { by teacher during the on-line } \\
\text { learning }\end{array}$} & Favourable & 9 & BEH1 \\
\hline & & & Unfavourable & 15 & $\mathrm{BEH} 2$ \\
\hline & & & & 10 & BEH3 \\
\hline & & & & 7 & BEH4 \\
\hline
\end{tabular}

or consistent. For the mathematics learning achievement, scores from one mathematics subject were used. The choice fell on the Geometry for semester 2, Numeric Method for semester 4, and Linear Program for semester 6.

Data collection was conducted in the following steps. Students were given the Google link for the mathematics anxieties questionnaire through the Whatsapp venue. Students filled out the questionnaire on-line at home, without supervision from the researcher, individually and autonomously.

Since the objective of the study was to find the level of the students' mathematics anxieties and the impacts on their on-line learning achievements, the data being analyzed were quantitative. Data analysis was done in the following steps: 1) identifying the students' responses; (2) calculating the average score for each of the mathematics anxieties aspects; 3) classifying the average score of the mathematics anxieties aspects into score intervals based on their means $(\bar{X})$ dan standard deviations $(S D)$; and 4 ) computing the descriptive statistics on the
SPSS Version 22 and the Confirmatory Factor Analysis (CFA) using the Structural Equation Model (SEM) on the Lisrel Program.

\section{FINDINGS AND DISCUSSION \\ Findings \\ Mathematics Anxieties Levels}

Results of the data analyses of the mathematics anxieties aspects of the 109 student subjects are shown in Table 3. This is followed up by further analyses to plot the scores into each of the anxieties aspects based on the determined criteria. The next step is calculating the frequencies and percentages of the anxiety aspects that is shown in Table 4. As it can be seen in Table 4, the mathematics anxieties in the physiological aspect is seen as the highest (38.53\%) in the highest category. In the cognitive aspect, the highest anxiety level is in the moderate category $(52.29 \%)$. In the affective aspect, the highest anxiety level is also in the moderate category (42.20\%). Similarly, the behavioral aspect also has its highest anxiety level in the moderate category (31.19\%). 
Table 3. Descriptive Statistics of the Mathematics Anxieties Aspects

\begin{tabular}{lccc}
\hline No. Mathematics Anxieties Aspects & $\boldsymbol{N}$ & Mean & Standard Deviation \\
\hline 1. Physiological & 109 & 2.96 & .606 \\
2. Cognitive & 109 & 2.81 & .490 \\
3. Affective & 109 & 3.05 & .636 \\
4. Behavioral & 109 & 2.93 & .687 \\
\hline Mean & 109 & 2.94 & .604885 \\
\hline
\end{tabular}

Table 4. Categorization of the Anxieties Aspects

\begin{tabular}{|c|c|c|c|c|c|c|c|c|c|c|}
\hline \multirow{3}{*}{ No. } & \multirow{3}{*}{ Score Interval } & \multicolumn{8}{|c|}{ Number of Students in the Anxieties Aspects } & \multirow{3}{*}{ Category } \\
\hline & & \multicolumn{2}{|c|}{ Physiological } & \multicolumn{2}{|c|}{ Cognitive } & \multicolumn{2}{|c|}{ Affective } & \multicolumn{2}{|c|}{ Behavioral } & \\
\hline & & $F$ & $\%$ & $F$ & $\%$ & $F$ & $\%$ & $F$ & $\%$ & \\
\hline 1. & $x>3.84$ & 5 & 4.59 & 1 & .92 & 10 & 9.17 & 12 & 11.01 & Very high \\
\hline 2. & $3.24<x \leq 3.84$ & 42 & 38.53 & 17 & 15.60 & 33 & 30.28 & 26 & 23.85 & High \\
\hline 3. & $2.63<x \leq 3.24$ & 37 & 33.94 & 57 & 52.29 & 46 & 42.20 & 34 & 31.19 & Moderate \\
\hline 4. & $2.03<x \leq 2.63$ & 12 & 11.01 & 24 & 22.02 & 11 & 10.09 & 24 & 22.02 & Low \\
\hline 5. & $x \leq 2.03$ & 13 & 11.93 & 10 & 9.17 & 9 & 8.26 & 13 & 11.93 & Very low \\
\hline & Total & 109 & 100 & 109 & 100 & 109 & 100 & 109 & 100 & \\
\hline
\end{tabular}

\section{Distribution of the Indicators of the Anxiety Aspects}

Results of the descriptive statistical analyses on the indicators of the anxiety aspects are displayed in Table 5. Calculation of these statistics was done by CFA and SEM tests. For all indicators of the aspects of mathematics anxieties, the mean score is found to be 2.939 with a standard deviation of 1.051 . This means that, on the average, all indicators tend to fall in the moderate category. However, two indicators in the affective aspects are found to be in the high category (AFF1 and AFF2). These two indicators are "students feel uneasy when the teacher explains materials in the on-learning" and "students feel frightened when learning mathematics on-line."

Table 5. Descriptive Statistics of the Indicators of the Anxiety Aspects

\begin{tabular}{clccc}
\hline No. & Indicator Code of the Anxiety Aspects & $\boldsymbol{N}$ & Mean & Std. Deviation \\
\hline 1. & PHY1 & 109 & 3.028 & 1.004 \\
2. & PHY2 & 109 & 2.917 & 1.115 \\
3. & PHY3 & 109 & 2.936 & 1.021 \\
4. & COG1 & 109 & 3.128 & .934 \\
5. & COG2 & 109 & 2.330 & 1.072 \\
6. & COG3 & 109 & 2.899 & .952 \\
7. & COG4 & 109 & 2.835 & 1.014 \\
8. & COG5 & 109 & 2.862 & 1.004 \\
9. & COG6 & 109 & 2.780 & 1.189 \\
10. & AFF1 & 109 & 3.798 & 1.145 \\
11. & AFF2 & 109 & 3.257 & 1.101 \\
12. & AFF3 & 109 & 2.872 & 1.131 \\
13. & AFF4 & 109 & 3.018 & .933 \\
14. & AFF5 & 109 & 3.284 & 1.089 \\
15. & AFF6 & 109 & 2.716 & 1.277 \\
16. & AFF7 & 109 & 2.422 & 1.133 \\
17. & BEH1 & 109 & 2.917 & .783 \\
18. & BEH2 & 109 & 2.844 & 1.029 \\
19. & BEH3 & 109 & 3.055 & 1.044 \\
20. & BEH4 & 109 & 2.890 & 1.066 \\
\hline & Mean & & 2.939 & 1.052 \\
\hline
\end{tabular}


Impacts of Mathematics Anxieties Aspects on Mathematics Learning Achievements

The impacts of mathematics anxieties on mathematics learning achievements can be seen from the results of CFA using SEM of the Lisrel program as shown in Figure 1. There are 20 indicators of the anxieties aspects; 4 physiological, 6 cognitive, 7 affective, and 4 behavioral.
In the Figure 1, scores are shown on the factor loading used to determine the impacts of the anxieties aspects on the on-line learning achievements. There are three criteria: high $(x$ $\geq .76)$, moderate $(.3 \leq x<.76)$, and low $(x<.3)$ (Nurgiyantoro, Lestyarini, \& Rahayu, 2020). Meanwhile, the contributions of the anxieties aspects on the learning achievements can be seen in Table 6.

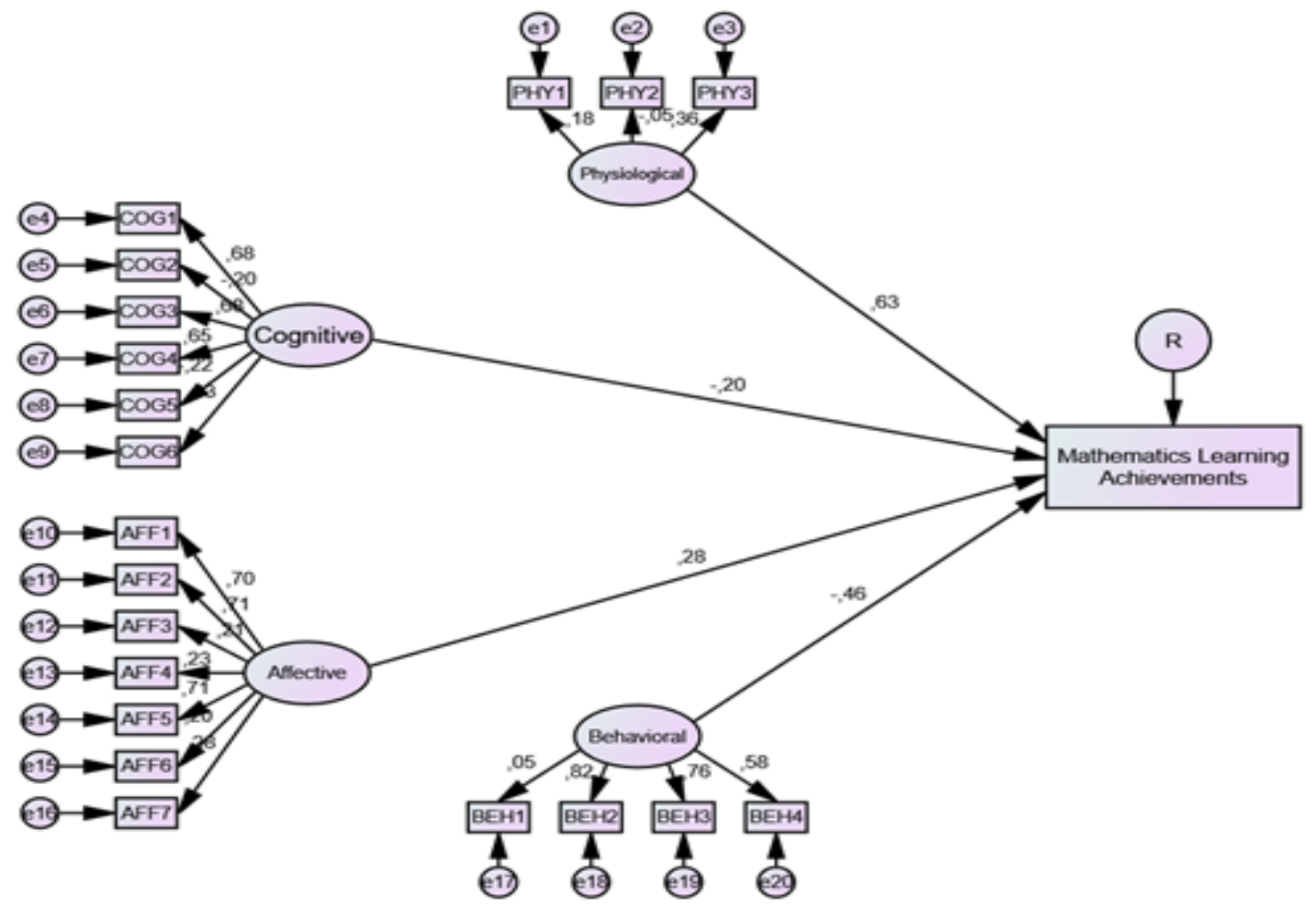

Figure 1. Impacts of Mathematics Anxieties Aspects on Mathematics Learning Achievements

Tabel 6. Contributions of the Mathematics Anxieties Aspects on the Mathematics Learning Achievements

\begin{tabular}{|c|c|c|c|c|c|}
\hline No. & Variable & Indicator & Loading Factor Score & Category & Note \\
\hline \multirow[t]{3}{*}{1.} & Physiological & PHY1 & .184 & Low & High $=5(25 \%)$ \\
\hline & & PHY2 & -.052 & Not convergent & Moderate $=6(30 \%)$ \\
\hline & & PHY3 & .359 & Moderate & Low $=6(30 \%)$ \\
\hline \multirow[t]{6}{*}{2.} & Cognitive & COG1 & .683 & Moderate & Not convergent $=3(15 \%)$ \\
\hline & & $\mathrm{COG} 2$ & -.204 & Not convergent & \\
\hline & & COG3 & .683 & Moderate & \\
\hline & & COG4 & 650 & Moderate & \\
\hline & & COG5 & -.221 & Not convergent & \\
\hline & & KOG6 & .430 & Moderate & \\
\hline \multirow[t]{7}{*}{3.} & Affective & AFF1 & .701 & High & \\
\hline & & AFF2 & .711 & High & \\
\hline & & AFF3 & .205 & Low & \\
\hline & & AFF4 & .232 & Low & \\
\hline & & AFF5 & .711 & High & \\
\hline & & AFF6 & .197 & Low & \\
\hline & & AFF7 & .282 & Low & \\
\hline \multirow[t]{4}{*}{4.} & Behavioral & BEH1 & .054 & Low & \\
\hline & & $\mathrm{BEH} 2$ & .819 & High & \\
\hline & & $\mathrm{BEH} 3$ & .761 & High & \\
\hline & & BEH4 & .576 & Moderate & \\
\hline
\end{tabular}


As it can be seen in Table 6, some indicators have a factor loading score lower than .5; it can be said that these indicators are not good enough for measuring physiological, cognitive, affective, and behavioral anxieties. sehingga indikator-indikator tersebut kurang baik dalam mengukur variabel fisiologi, kognitif, afektif, dan perilaku. Factor loading scores can be categorized as high $(25 \%)$, moderate $(30 \%)$, and a combination of low and not convergent $(45 \%)$. There are, then, 11 indicators that can be retained as contributors; that is, indicators of the high and moderate categories while the other indicators cannot be categorized as contributors; that is, they do not give significant contributions to the learning achievements of mathematics. This has a consequence on the re-evaluation of the determining factors, number of factors, and other contexts that have influence on learning achievements.

Figure 1 also shows the impacts of the physiological, cognitive, affective, and behavioral aspects of mathematics anxieties in relation to learning achievement. To point out which variables have influence on learning achievements, Table 7 can be used. It can be shown that physiological and behavioral aspects do not have significant impacts on learning strategies. This is seen from the values of the critical ratio which is less than 2 and $p$-value which is higher than .05. On the other hand, the cognitive and affective aspects of the anxieties have significant impacts from the facts that the critical ratio is larger than 2 and $p$-value is lower than .05 .

\section{Discussion}

\section{Levels of Mathematics Anxieties}

Many agree that studying mathematics is difficult even when instruction is done in a direct way (face-to-face); not to mention when it is done on-line. Such feelings of difficulty may cause mathematics anxieties. Mathematics anxieties are shown when one is nervous when studying mathematics or when solving mathematical problems. Mathematics anxieties have been found to have an impact on mathematics achievement, psychology, and neuroscience (Buckley, Reid, Goos, Lipp, \& Thomson, 2016). A special attention is therefore needed to be given as to the level of mathematics anxieties in on-learning, factors that cause mathematics anxieties, and ways to overcome or minimize mathematics anxieties.

The present study is attempting to find the levels of mathematics anxieties and the impacts of mathematics anxieties on mathematics learning achievements. Findings of this study show that three mathematics anxieties aspects (cognitive, affective, and behavioral) are dominated by the moderate category while the physiological aspect is dominated by the high category. These findings indicate that students of the mathematics study program experience anxieties in the proportional standard. Students have been able to handle their anxieties in their on-line learning in the cognitive, affective, and behavioral aspects. This is in agreement with the study of Pourmoslemi et al. (2013) who studied mathematics anxieties before the Covid-19 time, and found that students' mathematics anxieties level in mathematics learning was of the low level.

In the results of the data analyses of the students' questionnaires, it was found that, in every aspect, there were few students who scored very high (around $1 \%$ to $11 \%$ ), and high (15\% to $38 \%$ ). This means that there are a considerable number of students who are not able yet to overcome their anxieties well. This fact can be taken to lead to the understanding that, for a number of students, on-line learning becomes

Tabel 7. Standardized Co-efficient and Significance Level Model

\begin{tabular}{lcccl}
\hline Relation & $\begin{array}{c}\text { Standardized } \\
\text { Co-efficient }\end{array}$ & $\begin{array}{c}\text { Critical } \\
\text { Ratio }\end{array}$ & $\boldsymbol{p}$-Value & Conclusion \\
\hline Physiological $\rightarrow$ Learning achievement & .632 & .711 & .477 & Not significant \\
Cognitive $\rightarrow$ Learning achievement & -.205 & -2.140 & .032 & Significant \\
Affective $\rightarrow$ Learning achievement & .284 & 2.946 & .003 & Significant \\
Behavioral $\rightarrow$ Learning achievement & -.464 & -.507 & .612 & Not significant \\
\hline
\end{tabular}


one of the causes of mathematics anxieties. This must be taken into account by teachers since mathematics anxieties of the very high or high level tend to cause students' mathematics anxieties in their students classes. In a different way, Buckley et al. (2016) stated that high mathematics anxieties will influence students' learning either in a short or longer range. The short-term influence appears in the form of students' low level of fluency/comprehension in the instructional contents while the longterm influence occurs in their teaching expertise (Cates \& Rhymer, 2003).

Score distribution of anxieties aspects shows an average for the moderate category although 2 of the 20 indicators have a mean score of the high category. These two indicators that are of the affective aspects refer to how students feel uneasy when attending the teacher's explanation on the class material and how students feel frightened when studying mathematics through the on-line mode. This is in line with Rubinsten \& Tannock (2010) who defined mathematics anxieties as negative affective responses and have negative effects on mathematics performances. In addition, mathematics anxieties have direct influences over students' emotions.

\section{Impacts of Mathematics Anxieties on Mathematics Learning Achievements}

The level of students' mathematics anxieties gives an impact on their on-line learning achievements. The impact takes the form of the various aspects of mathematics anxieties that have an influence on learning achievement. Results of the study, as presented above, show that the cognitive and affective aspects of the mathematics anxieties give significant influences on learning achievements. The cognitive aspects of mathematics anxieties take the forms such as difficulty to focus on class, make decision, and solve mathematics problems. The affective aspects appear in feelings of nervousness, fright, and anxiety when attending on-line mathematics classes. These phenomena are also explained by Erzen (2017) who stated that mathematics anxieties have a negative and significant influence on learning achievements.

Results of the SEM analyses indicate that the physiological and behavioral mathematics anxieties do not have significant impacts on learning achievements. However, these anxiety aspects need to be given attention since data show that the levels of the anxieties are high enough for the first $(38.53 \%)$ and the latter (23.85\%). Lai, Zhu, Chen, \& Li (2015) stated that any sign of mathematics anxieties must be taken into account as they will interfere with students' learning.

From the degree of contribution of the indicators of the anxieties aspects, it is found that 11 of the 20 indicators show contributions on learning achievements. These 11 indicators occur in all the four aspects of anxieties. In this case, it can be stated that all the four mathematics anxieties aspects have direct impacts on learning achievements by different degrees. Mathematics anxieties are related closely to cognitive reflections (Morsanyi et al., 2014).

Mathematics anxieties influence mathematics performances in two ways (Buckley et al., 2016). First, through physiological response interpretation, the emerging responses accelerate heart beats and breathing paces and disturb the work of the brain in solving mathematical problems. Second, through affective response interpretation, negative responses such as negative thoughts disturb cognitive functioning and interfere with memory performance processes. It is therefore important that all signs of mathematics anxieties be taken into account as they will interfere with the work of the physical organs that will negative impacts on learning achievements.

It goes without saying that a mathematics teacher needs to know characteristics of the students who experience mathematics anxieties whether of the physiological, cognitive, affective, or behavioral aspect. It is by knowing students' mathematics anxieties that the teacher will be able to help them solve or minimize their problems using various ways. Mathematics anxieties are instructional problems that need to be given attention and solution. In minimizing students' problems in mathematics anxieties, the teacher needs to pay attention on instructional interactivities of the high degree Allen \& ValléeTourangeau (2016). A high degree of learning interactivities will help students so that their mathematics anxieties will no longer interfere with their mathematics performances.

It is no doubt that parents' roles can also help in preventing or minimizing students' mathematics anxieties (Demirtaş \& Uygun- 
Eryurt, 2020). In this case, the father and mother become influential figures in helping students cope with anxieties. Parents' support is greatly efficient in helping students when they experience problems in understanding mathematical concepts or solving mathematical problems. It is therefore true that there are many ways that can be done to help prevent the occurrence of mathematics anxieties.

\section{Implication}

Students' mathematics anxieties must become a point of attention by the mathematics teacher especially during the time of the Covid-19 pandemic. It is found that students' mathematics anxieties are generally in the moderate level; however, some students have high or very high levels of anxieties in certain anxieties aspects. Therefore, the teacher can create positive learning habits such as facilitating students with cooperative and responsive learning, giving enough tolerance to students who have problems with the Internet speed, giving transparent score grading, providing students with fun learning, and others. In their study, Chen et al. (2013) stated that learning habits have a significant relation with mathematics anxieties; the lower of the learning habit is, the higher the mathematics anxieties are.

As for the holders of the educational management, it is necessary to look at the curriculum especially in relation to the Covid-19 pandemic on-line learning. There is a difference in the treatment of the instructional processes between the curriculum during the pandemic and the curriculum of the face-to-face instruction. This will help all instructional efforts so that students will not experience mathematics anxieties in their mathematics learning. In this case, Daniel (2020) stated that the institution and teachers need to determine the points of the contents of the curriculum that need to be given special attention to achieve the learning outcomes.

\section{CONCLUSION}

This study is envisaged to yield the following points of conclusion: (1) students' levels of mathematics anxieties are bound to be in the moderate category in the cognitive, affective, and behavioral aspects and high in the physiological aspect. This shows that students of the mathematics study program have mathematics anxieties of the standard proportion. Students are able to cope with their mathematics anxieties in the cognitive, affective, and behavioral aspects during their online mathematics learning; (2) the mathematics anxieties aspects that have significant impacts on students' learning achievements are those of the cognitive and affective. The cognitive aspects refers to anxieties that are related to their thought processes while the affective aspects to their feelings. These two mathematics anxieties influence negatively and significantly on their academic achievements.

A suggestion for future researchers is to conduct research on mathematics anxieties not only using a questionnaire as the research instrument, but also an observation to more indepth data. Indicators of mathematics anxieties can be well identified using direct observation.

\section{DAFTAR PUSTAKA}

Agarwal, S., \& Kaushik, J. S. (2020). Student's perception of online learning during COVID pandemic. Indian Journal of Pediatrics, 87(7), 554. https://doi. org/10.1007/s12098-020-03327-7.

Allen, M., \& Vallée-Tourangeau, F. (2016). Interactivity defuses the impact of Mathematics anxiety in primary school children. International Journal of Science and Mathematics Education, 14(8), 15531566. https://doi.org/10.1007/s10763015-9659-9.

Almaiah, M. A., Al-Khasawneh, A., \& Althunibat, A. (2020). Exploring the critical challenges and factors influencing the e-learning system usage during COVID-19 pandemic. Education and Information Technologies, 25(6), 52615280. https://doi.org/10.1007/s10639020-10219-y.

Ayyala, R. S., Taylor, G. A., \& Callahan, M. J. (2020). Stresses and anxieties in the time of the COVID-19 pandemic - what we can learn. Pediatric Radiology, 50(8), 1052-1054. https://doi.org/10.1007/ s00247-020-04727-9.

Bal, I. A., Arslan, O., Budhrani, K., Mao, Z., 
Novak, K., \& Muljana, P. S. (2020). The balance of roles: Graduate student perspectives during the COVID-19 pandemic. TechTrends, 64(6), 796-798. https://doi.org/10.1007/s11528-02000534-z.

Baloğlu, M., \& Zelhart, P. F. (2007). Psychometric properties of the revised mathematics anxiety rating scale. The Psychological Record, 57(4), 593-611. https://doi.org/10.1007/BF03395597.

Bekdemir, M. (2010). The pre-service teachers' mathematics anxiety related to depth of negative experiences in mathematics classroom while they were students. Educational Studies in Mathematics, 75(3), 311-328. https://doi.org/10.1007/ s10649-010-9260-7.

Bloom, D. A., Reid, J. R., \& Cassady, C. I. (2020). Education in the time of COVID-19. Pediatric Radiology, 50(8), 1055-1058. https://doi.org/10.1007/s00247-02004728-8.

Buckley, S., Reid, K., Goos, M., Lipp, O. V., \& Thomson, S. (2016). Understanding and addressing mathematics anxiety using perspectives from education, psychology and neuroscience. Australian Journal of Education, 60(2), 157-170. https://doi. org/10.1177/0004944116653000.

Cates, G., \& Rhymer, K. (2003). Examining the relationship between Mathematics anxiety and Mathematics performance: An instructional hierarchy perspective. Journal of Behavioral Education, 12(1), 23-34. https://doi. org/10.1023/A:1022318321416.

Chaman, M. J., Beswick, K., \& Callingham, R. (2014). Factors influencing mathematics achievement among secondary school students: A review. In N. Fitzallen, R. Reaburn, \& S. Fan (Eds.). The future of educational research: perspectives from beginning researchers. Rotterdam, The Netherlands: Sense publishers, pp. 227238. https://doi.org/10.1007/978-946209-512-0.
Chen, B. H., Hsu, M.-S., \& Chen, M.-H. (2013). The relationship between learning attitude and anxiety in accounting classes: The case of hospitality management university students in Taiwan. Quality and Quantity, 47(5), 2815-2827. https:// doi.org/10.1007/s11135-012-9691-6.

d'Orville, H. (2020). COVID-19 causes unprecedented educational disruption: Is there a road towards a new normal? Prospects, 49(1), 11-15. https://doi. org/10.1007/s11125-020-09475-0.

Daniel, S. J. (2020). Education and the COVID-19 pandemic. Prospects, 49(1), 91-96. https://doi.org/10.1007/s11125020-09464-3.

Demirtaş, A. S., \& Uygun-Eryurt, T. (2020). Attachment to parents and math anxiety in Early adolescence: Hope and perceived school climate as mediators. Current Psychology. $\quad$ https://doi.org/10.1007/ s12144-020-00964-1.

Ehrlich, H., McKenney, M., \& Elkbuli, A. (2020). We asked the experts: Virtual learning in surgical education during the COVID-19 pandemic - shaping the future of surgical education and training. World Journal of Surgery, 44(7), 2053-2055. https://doi. org/10.1007/s00268-020-05574-3.

Erzen, E. (2017). The effect of anxiety on student achievement. In E. Karadağ (Ed.). The factors effecting student achievement: Meta-analysis of empirical studies. Switzerland, AG: Springer International Publishing, pp. 75-94. https://doi. org/10.1007/978-3-319-56083-0.

Gafoor, K., \& Kurukkan, A. (2015, 18-19 August). Why high school students feel mathematics difficult? An exploration of affective beliefs. Paper presented at the UGC Sponsored National Seminar on Pedagogy of Teacher Education, Trends and Challenges, Kozhikode, Kerala, India. https://doi.org/10.13140/ RG.2.2.18880.12800.

Greenberger, D., \& Padesky, C. A. (1995). Mind over mood: Change how you fee! by 
changing the way you think. New York, NY: Guiltford Press.

Guita, G. B., \& Tan, D. A. (2018). Mathematics anxiety and students' academic achievement in a reciprocal learning environment. International Journal of English and Education, 7(3), 112-124. http://www.ijee.org/yahoo site admin/ assets/docs/9.20070544.pdf.

Huang, R., Tlili, A., Chang, T. W., Zhang, X., Nascimbeni, F., \& Burgos, D. (2020). Disrupted classes, undisrupted learning during COVID-19 outbreak in China: application of open educational practices and resources. Smart Learning Environments, 7(1), 1-15. https://doi. org/10.1186/s40561-020-00125-8.

Huang, X., Zhang, J., \& Hudson, L. (2019). Impact of math self-efficacy, math anxiety, and growth mindset on math and science career interest for middle school students: The gender moderating effect. European Journal of Psychology of Education, 34(3), 621-640. https://doi.org/10.1007/ s10212-018-0403-z.

Huber, S. G., \& Helm, C. (2020). COVID-19 and schooling: Evaluation, assessment and accountability in times of crises - reacting quickly to explore key issues for policy, practice and research with the school barometer. Educational Assessment, Evaluation and Accountability, 32(2), 237-270. https://doi.org/10.1007/s11092020-09322-y.

Iyengar, R., \& Shin, H. (2020). Communitybased programs to tackle environmental education and COVID-19: A case study from Millburn, New Jersey. Prospects. https://doi.org/10.1007/s11125-02009467-0.

Kerres, M. (2020). Against all odds: Education in Germany coping with Covid-19. Postdigital Science and Education, 2(3), 690-694. https://doi.org/10.1007/s42438020-00130-7.

Kim, J. (2020). Learning and teaching online during Covid-19: Experiences of student teachers in an early childhood education practicum. International Journal of Early Childhood, 52(2), 145-158. https://doi. org/10.1007/s13158-020-00272-6.

Kramarski, B., Weisse, I., \& Kololshi-Minsker, I. (2010). How can self-regulated learning support the problem solving of third-grade students with mathematics anxiety? ZDM, 42(2), 179-193. https://doi.org/10.1007/ s11858-009-0202-8.

Lai, Y., Zhu, X., Chen, Y., \& Li, Y. (2015). Effects of mathematics anxiety and mathematical metacognition on word problem solving in children with and without mathematical learning difficulties. PLOS ONE, 10(6), 1-19. https://doi.org/10.1371/journal. pone. 0130570 .

Lewis, D. (2020). Student anxiety in standardsbased grading in Mathematics courses. Innovative Higher Education, 45(2), 153164. https://doi.org/10.1007/s10755-01909489-3.

Lopes, H., \& McKay, V. (2020). Adult learning and education as a tool to contain pandemics: The COVID-19 experience. International Review of Education, 66(4), 575-602. https://doi.org/10.1007/s11159020-09843-0.

Lubis, A. H. (2018). ICT integration in 21st -century indonesian English language teaching: Myths and realities. Cakrawala Pendidikan, 37(1), 11-21. https://doi. org/10.21831/cp.v37i1.16738.

Mamun, M. A., Chandrima, R. M., \& Griffiths, M. D. (2020). Mother and Son Suicide Pact due to COVID-19-related online learning issues in Bangladesh: An unusual case report. International Journal of Mental Health and Addiction, 1-4. https:// doi.org/10.1007/s11469-020-00362-5.

McMinn, M., \& Aldridge, J. (2019). Learning environment and anxiety for learning and teaching mathematics among preservice teachers. Learning Environments Research, 23(3), 331-345. https://doi. org/10.1007/s10984-019-09304-y. 
Morsanyi, K., Busdraghi, C., \& Primi, C. (2014). Mathematical anxiety is linked to reduced cognitive reflection: A potential road from discomfort in the mathematics classroom to susceptibility to biases. Behavioral and Brain Functions, 10(1), 1-13. https://doi. org/10.1186/1744-9081-10-31.

Nuere, S., \& de Miguel, L. (2020). The digital/ technological connection with COVID-19: An unprecedented challenge in university teaching. Technology, Knowledge and Learning. https://doi.org/10.1007/s10758020-09454-6.

Nurgiyantoro, B., Lestyarini, B., \& Rahayu, D. H. (2020). Mapping junior high school students' functional literacy competence. Cakrawala Pendidikan, 39(3), 560-572. https://doi.org/10.21831/cp.v39i3.34061.

Nurhayati, N., Marhayani, D. A., Chang, C.-H., \& Naaranoja, M. (2019). Math anxiety analysis in Indonesian elementary school. In L. Uden, D. Liberona, G. Sanchez, S. Rodríguez-González (Eds.). Learning technology for education challenges, International Workshop on Learning Technology for Education in Cloud. Switzerland, AG: Springer, Cham, pp. 292-301.

Pourmoslemi, A., Erfani, N., \& Firoozfar, I. (2013). Mathematics anxiety, Mathematics performance and gender differences among undergraduate students. International Journal of Scientific and Research Publications, 3(7), 3-8. http:// www.ijsrp.org/research-paper-0713. php?rp=P191433.

Radišić, J., Videnović, M., \& Baucal, A. (2015). Math anxiety-contributing school and individual level factors. European Journal of Psychology of Education, 30(1), 1-20. https://doi.org/10.1007/s10212-014$\underline{0224-7 .}$.

Ramrathan, L. (2020). School curriculum in South Africa in the Covid-19 context: An opportunity for education for relevance. Prospects. $\quad$ https://doi.org/10.1007/ s11125-020-09490-1.
Ray, S., \& Srivastava, S. (2020). Virtualization of science education: a lesson from the COVID-19 pandemic. Journal of Proteins and Proteomics, 11(2), 77-80. https://doi. org/10.1007/s42485-020-00038-7.

Rayner, V., Pitsolantis, N., \& Osana, H. (2009). Mathematics anxiety in preservice teachers: Its relationship to their conceptual and procedural knowledge of fractions. Mathematics Education Research Journal, 21(3), 60-85. https:// doi.org/10.1007/BF03217553.

Rubinsten, O., \& Tannock, R. (2010). Mathematics anxiety in children with developmental dyscalculia. Behavioral and Brain Functions, 6(1), 1-13. https:// doi.org/10.1186/1744-9081-6-46.

Schneider, S. L., \& Council, M. L. (2020). Distance learning in the era of COVID-19. Archives of Dermatological Research, 3-4. https://doi.org/10.1007/s00403-02002088-9.

Skaalvik, E. M. (2018). Mathematics anxiety and coping strategies among middle school students: relations with students' achievement goal orientations and level of performance. Social Psychology of Education, 21(3), 709-723. https://doi. org/10.1007/s11218-018-9433-2.

Soni, A., \& Kumari, S. (2017). The role of parental Math anxiety and Math attitude in their children's Math achievement. International Journal of Science and Mathematics Education, 15(2), 331-347. https://doi.org/10.1007/s10763-0159687-5.

Spaull, N. (2020). COVID-19 and schooling in South Africa: Who should go back to school first? Prospects. https://doi. org/10.1007/s11125-020-09470-5.

Tambychik, T., \& Meerah, T. S. M. (2010). Students' difficulties in mathematics problem-solving: What do they say? Procedia - Social and Behavioral Sciences, 8(5), 142-151. https://doi. org/10.1016/j.sbspro.2010.12.020. 
Taylor, B. A., \& Fraser, B. J. (2013). Relationships between learning environment and mathematics anxiety. Learning Environments Research, 16(2), 297-313. https://doi.org/10.1007/s10984013-9134-x.
Vásquez-Colina, M., Gonzalez-DeHass, A., \& Furner, J. (2014). Achievement goals, motivation to learn, and Mathematics anxiety among pre-service teachers. Journal of Research in Education, 24(1), 38-52. https://files.eric.ed.gov/fulltext/ EJ1098234.pdf. 